\title{
Happiness and satisfaction with life: potential social indicators for periodic measurement in Brasil?
}

(D) Mayara Goulart de Camargos ${ }^{1,2^{*}}$

(D) Bianca Sakamoto Ribeiro Paiva²

(iD) Marco Antônio de Oliveira ${ }^{2,3}$

(iD Carla Simone Leite de Almeida ${ }^{4}$

(iD) Carlos Eduardo Paiva 2,5

\begin{abstract}
1. Hospital de Clínicas da Universidade Federal do Triângulo Mineiro (UFTM), Uberaba, MG, Brasil. 2. Grupo de Pesquisa em Cuidados Paliativos e Qualidade de Vida Relacionada à Saúde (GPQual), Instituto de Ensino e Pesquisa, Hospital de Câncer de Barretos, Barretos, SP, Brasil. 3. Centro de Epidemiologia e Bioestatística, Hospital de Câncer de Barretos, Barretos, SP, Brasil. 4. Instituto Federal de Educação, Ciência e Tecnologia de Santa Catarina, Joinville, SC, Brasil. 5. Departamento de Oncologia Clínica, Hospital de Câncer de Barretos, Barretos, SP, Brasil.
\end{abstract}

Dear Editor,

In essence, all human beings are in pursuit of happiness, a multidimensional and complex construct that is the result of individual subjective experiences ${ }^{1}$. Thus, it is challenging to compare data on happiness and its multidimensional measures between different cultures and specific populations ${ }^{1}$. Studies on happiness have gained increasing attention, not only from researchers but also in journalistic and political debates since happiness indices are also used as indicators of economic growth and social development and are already included in public policies in several countries ${ }^{2}$.

The Sustainable Development Solutions Network, linked to the United Nations (UN), has been publishing since 2013, the global happiness ranking called the World Happiness Report. It is based on how happy people feel, but it also estimates how much of this happiness is influenced by the Gross Domestic Product (GDP) per capita, public policies, life expectancy, generosity, levels of corruption, and individual free$\mathrm{dom}^{2}$. Among a total of 156 countries, Brasil ranked in the 22nd, 28th, and 32nd positions in 2017, 2018, and 2019 , respectively. The best ranking was recorded in 2014 , in the 17th position ${ }^{2}$. Thus, Brasil still does not feature among the countries with the highest levels of happiness, indicating a potential for improving the planning and development of public policies geared to this purpose ${ }^{2}$.

Our research group on Quality of Life has assessed happiness and satisfaction with life indices among health professionals, students, chronic patients, and their caregivers. Recently, we evaluated 
TABLE 1. AVERAGES OF HAPPINESS AND SATISFACTION WITH LIFE BASED ON THE HUMAN DEVELOPMENT INDEX (HDI) AND SOCIAL VULNERABILITY INDEX (SVI) IN THE CITIES IN WHICH THE PARTICIPANTS LIVED

\begin{tabular}{|c|c|c|c|c|}
\hline Variable & $\mathrm{HDI}$ and SVI & Mean (SD) & $\begin{array}{l}\text { Median } \\
\text { (Minimum/Maximum) }\end{array}$ & $\mathrm{p}$-value \\
\hline \multirow[t]{10}{*}{ Happine $^{\text {ssa }}$} & \multicolumn{3}{|l|}{ HDI } & \multirow[t]{5}{*}{0.076} \\
\hline & Very low/Low & $7.50(2.12)$ & $8.18(2.18-10.00)$ & \\
\hline & Medium & $7.18(1.79)$ & $7.55(2.00-10.00)$ & \\
\hline & High & $6.91(2.01)$ & 7.45 (0.09- 10.00) & \\
\hline & Very high & $7.12(1.82)$ & $7.64(0.18-10.00)$ & \\
\hline & \multicolumn{3}{|l|}{ SVI } & \multirow[t]{5}{*}{0.392} \\
\hline & Very low & $7.08(1.89)$ & $7.55(0.27-10.00)$ & \\
\hline & Low & $6.99(1.94)$ & $7.55(0.09-10.00)$ & \\
\hline & Medium & $6.85(2.05)$ & $7.27(0.64-10.00)$ & \\
\hline & High/Very high & $7.22(2.11)$ & $8.00(2.18-10.00)$ & \\
\hline \multirow[t]{10}{*}{ Satisfaction with life ${ }^{b}$} & \multicolumn{3}{|l|}{$\mathrm{HDI}$} & \multirow[t]{5}{*}{0.759} \\
\hline & Very low/Low & $25.26(6.64)$ & $25.00(13.00-35.00)$ & \\
\hline & Medium & $24.32(6.65)$ & $26.00(7.00-35.00)$ & \\
\hline & High & $24.65(6.75)$ & $26.00(5.00-35.00)$ & \\
\hline & Very high & $24.91(6.64)$ & $26.00(5.00-35.00)$ & \\
\hline & \multicolumn{3}{|l|}{ SVI } & \multirow[t]{5}{*}{0.004} \\
\hline & Very low & $25.55(6.51)$ & $27.00(5.00-35.00)$ & \\
\hline & Low & $24.63(6.71)$ & $26.00(5.00-35.00)$ & \\
\hline & Medium & $23.76(6.93)$ & $25.00(5.00-35.00)$ & \\
\hline & High/Very high & $24.17(6.39)$ & $25.00(7.00-34.00)$ & \\
\hline
\end{tabular}

a Assessed based on the Pemberton Happiness Index (PHI). b Assessed based on the Satisfaction With Life Scale (SWLS). Human Development Index (HDI): Very low: 0.000 0.499/Low: 0.500 - 0.599/Medium: 0.600 - 0.699/High: 0.700 - 0.799/Very high: 0.800 - 1.000. Social Vulnerability Index (SVI): Very low: 0.000 - 0.199/Low: 0.200 - 0.299/ Medium: $0.300-0.399 /$ High: $0.400-0.499 /$ Very high: $0.500-1.000$.

the happiness and satisfaction with life indices in a sample of the general Brazilian population that uses social media. To do that, participants responded to the Pemberton Happiness Index (PHI) and the Satisfaction With Life Scale (SWLS), duly validated for use in Portuguese/Brasil ${ }^{3}$. We identified that out of the 2,151 participants, $1,311(60.9 \%)$ considered themselves happy. There was no difference between the North (63.2\% [95\% CI:56-70]), Northeast (62.1\% [95\% CI:56-68]) and Central-West (60.4\% [95\% CI:53-68]) regions or in relation to the others regions. However, although the analyses included only users of social media, the results showed that residents of the South region (66.9\% [95\% CI:63-71]) reported being happier than those in the Southeast (56.9\% [95\% CI:54-60]). The South of Brasil, which historically was influenced by European colonization, had already previously presented, in other studies, above-average indices of happiness ${ }^{4,5}$.

Most participants lived in municipalities with high human development index scores (HDI; n=1361; 63.3\%) and low social vulnerability indexes (SVI; $n=1,373$; $63.8 \%$ ). The municipalities' HDI scores had no influence on the averages of happiness and satisfaction with life; however, participants were less satisfied in cities with higher SVI (Table 1).

The SVI evaluates the absence or deficiency of resources essential for the well-being and quality of life of the population, characterizing, thus, situations of social vulnerability; the higher the index, the greater the vulnerability. In 2010, the Brazilian SVI was 0.326 , and it decreased to 0.243 (in 2014) and 0.248 (in 2015) ${ }^{6}$.

The publications of the results from this study could stimulate managers to optimize public policies appropriate to the reality of each area, large or small, in order to benefit the quality of life and, consequently, the more vulnerable populations' satisfaction with life. Furthermore, we believe that measurements of happiness and the constructs involved in it should be considered potential social indicators for periodic assessment in our country. 


\section{REFERENCES}

1. Boehm JK, Lyubomirsky S, Sheldon KM. A longitudinal experimental study comparing the effectiveness of happiness-enhancing strategies in Anglo Americans and Asian Americans. Cogn Emot. 2011;25(7):1263-72.

2. Helliwell JF, Layard R, Sachs JD. World happiness report 2019. New York; 2019. [cited 2019 Sep 2]. Available from: https://s3.amazonaws.com/happiness-report/2019/WHR19.pdf

3. Camargos MG, Paiva BSR, Almeida CSL, Paiva CE. What is missing for you to be happy? Comparison of the pursuit of happiness among cancer patients, informal caregivers, and healthy individuals. I Pain Symptom Manage. 2019;58(3):417-26.

4. Scalco DL, Araújo CL, Bastos JL. Autopercepção de felicidade e fatores associados em adultos de uma cidade do sul do Brasil: estudo de base populacional. Psicol: Reflex Crít. 2011;24(4):648-57.
5. Bastos CC, Closs VE, Pereira AMVB, Batista C, Idalêncio FA, De Carli GA, et al. Importância atribuída ao sexo por idosos do município de Porto Alegre e associação com a autopercepção de saúde e o sentimento de felicidade. Rev Bras Geriatr Gerontol. 2012;15(1):87-95.

6. Instituto de Pesquisa Econômica Aplicada (IPEA). A nova plataforma da vulnerabilidade social: primeiros resultados do Índice de Vulnerabilidade Social para a série histórica da PNAD (2011-2015) e desagregações por sexo, cor e situação de domicílios. Rio de Janeiro: Instituto de Pesquisa Econômica Aplicada; 2018. [cited 2019 Sep 2]. Available from: http:// www.ipea.gov.br/portal/images/stories/PDFs/relatorio_institucional/180515_relatorio_institucional_a_nova_plataforma_da_vulnerabilidade_social.pdf. 